\title{
Arno G. Motulsky, MD (1923-2018): Holocaust survivor who cofounded the field of medical genetics
}

\author{
Gail P. Jarvik, MD, PhD
}

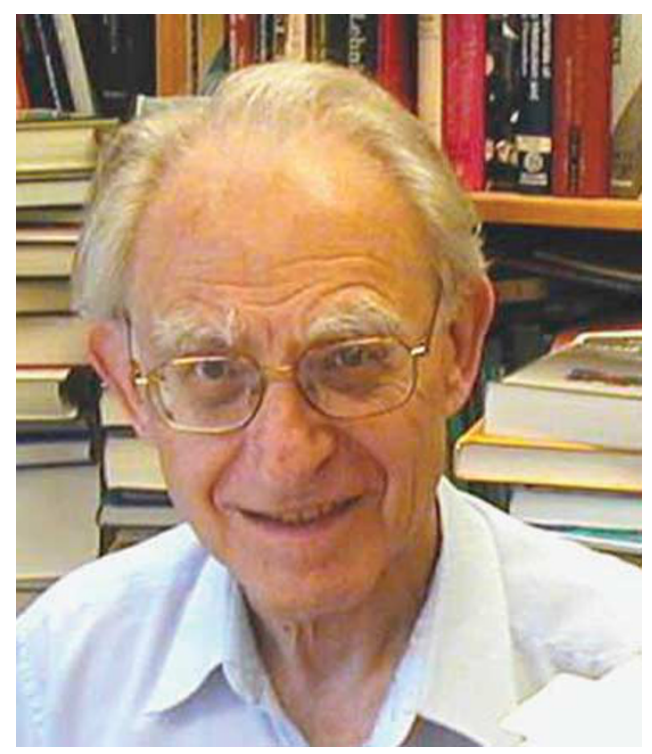

Arno at his desk (some piles having been moved out of the way), circa 2000.

Arno Gunther Motulsky led a remarkable life, moving from refugee and concentration camp survivor to a founder of the field of medical genetics. He pioneered research on the genetics of common diseases, and is recognized as "the father of pharmacogenetics". The New York Times obituary for Arno Motulsky quoted Frances Collins (Director of the National Institutes of Health) as saying "It was his vision to study how heredity could be involved in practically everything." To Arno, all human variation was ripe for evaluation for the contribution of genetic variation. His contemporaries and physician cofounders of medical genetics, Victor McKusick and James Neel, were better known for their studies of Mendelian disorders and population genetics, respectively. Arno embraced the study of all of complex disease (common disorders with many genetic and environmental contributors) as a tractable problem in human genetics. It was his genius to be able to both recognize and untangle these disorders, long before modern techniques and big data increased our tools.

\section{Escape from the holocaust}

Elsewhere, he tells the story of his early life in Germany, his saga as a passenger on the S.S. St. Louis, being refused entry to the United States and returning to Europe in June 1939. ${ }^{1}$ Other publications largely skip over his travails after he was refused entry to the United States and sent to Belgium. When the Germans attacked Belgium in May 1940, he was 16 years old and held a visa to the United States. He was separated from his family and arrested with German men-Nazis and Jews alike-over 16 years of age. They were transported by a series of crowded cattle cars without water and food, with one journey lasting 52 hours. They suffered from jeers and stone throwing and the inhumanity of (and repeated thefts by) first Belgian and then Vichy French guards. During his four 
months at Camp St. Cyprien, conditions were overcrowded, food was scarce, beds were made from a few straws on the ground, and rodents, fleas, dysentery, and typhoid fever were plentiful. When Belgium fell, the Nazis were released, but the Jews remained. His visa had expired.

In October 1940, Arno was moved to Gurs in southwest France, now run by the Vichy French. Arno wrote in 1941: "If we had called St. Cyprien hell, this (Gurs) was a super hell." The camp did not drain, and everyone trudged through mud at all times; Arno told of extracting a 75-year-old woman who had fallen and was stuck in the mud. There was little food, heat, or light, and no sanitation. Large numbers of prisoners died of starvation, and dysentery was widespread. Food sent by French Jews and the Swiss saved many lives, particularly those of children. Education and performances among prisoners were allowed and benefited Arno, who had been forced from school in Germany in 1938 for being Jewish.

Obtaining a French exit visa in March 1942 allowed Arno to move to the more tolerable emigration camp Les Milles, near Marseilles. There, he traveled 18 miles daily to consulates, seeking a new visa. By April, when the US entry visa looked promising, his French exit visa had expired. After renewing that and finding a ship from Lisbon to the United States, he faced the challenge of obtaining a transit visa to travel across Spain to Portugal. These were denied to Jewish men over 18 years, and he would turn 18 in July. He was lucky to obtain the transit visa just weeks before he would have been detained in France. Once he arrived in Portugal, there were further complications, but Arno arrived in New York in the late summer of 1941.

\section{Early career}

Having witnessed so much death at an early age, Arno joined the US military and became a physician scientist. In 1946, he began studying hemoglobinopathies with Karl Singer at Michael Reese Hospital in Chicago during his residencies in medicine and hematology there. He earned his MD at the University of Illinois at Chicago in 1947. His interest in hemoglobin landed him at Walter Reed studying spherocytosis with William Crosby.

In 1953, Arno accepted a position in the Department of Medicine at the University of Washington in Seattle. He continued his work on hemoglobinopathies, describing the use of paper electrophoresis to further phenotype them, ${ }^{2}$ as well as human cases and animal models. Known for his focus on teaching human genetics, the Medicine chair asked him to found a Division of Medical Genetics. He did this in 1957-the same year Victor McKusick at Johns Hopkins also founded one of the first medical genetics programs in the world.

\section{Scientific contributions}

Arno is recognized as "the father of pharmacogenetics." $\mathrm{He}$ first studied genetic variation in drug response in the 1950s and coined the term "pharmacogenetics" in
1960. He was the first to articulate how the understanding of genetic variation could lead to drug selection that was based on the needs of the individual-presaging precision medicine.

Over time, Arno expanded the diverse parts of medicine he thought worthy of genetic investigation, often later passing these areas of study to his trainees. In the 1960s, he looked at global variation in human blood and serum groups, considered biochemical genetics, framed Werner syndrome as a model in the genetics of aging $^{3}$ (with trainee Charles Epstein), and turned his attention to Mendelian and cytogenetic causes of birth defects. He recruited George Stamatoyannopoulos, MD to join his faculty, and they collaborated on the genetics of glucose-6-phosphate dehydrogenase deficiency, as well as the population genetics of blood groups and other protein polymorphisms. By 1970, Arno addressed genetic variation as a risk factor in anesthesia. In 1971, he and Gil Omen published on genetics and human behavior. ${ }^{4}$

Working with a promising trainee, Joseph Goldstein, who arrived in 1970, Arno suggested that lipids were a field for genetic variability exploration. This led to their landmark 1972 papers, with others, describing the transmission of hyperlipidemia in the families of individuals ascertained for early coronary atherosclerosis, ${ }^{5}$ and proposing that familial hypercholesterolemia was a monogenic disorder. ${ }^{6}$ In 1985, Arno would see Joe Goldstein awarded the Nobel Prize in Physiology or Medicine with Michael Brown "for their discoveries concerning the regulation of cholesterol metabolism," including determining the molecular basis of this Mendelian disorder. ${ }^{7}$ Arno continued to work with lipids throughout his career.

Ecogenetics, multifactorial disease, and pharmacogenetic issues, the genetics of Jewish populations, human leukocyte antigen associations, genetic linkage, and bioethical problems (including abortion) in genetics were foci of his activity in the late 1970s. Later, Arno's ever-expanding list of traits added hypertension, nutrition, alcoholism, color vision, and pesticide metabolism.

\section{Training and mentoring}

Arno's career was marked by bold ideas, keen insights, outstanding patient care, and inspired mentoring. ${ }^{8}$ The University of Washington Division of Medical Genetics has awarded a training grant for clinical genetics education continuously since Arno received it over 40 years ago. Arno had trained many of the luminaries in the field-scientists and leaders throughout the country and the world. Arno and his early trainees reported that for two decades they simply went over to the hospital wards, pulled inpatient charts for review until they found an interesting patient, and then consulted themselves.

One notable feature of Arno's career, given the era, was the number of women he trained, all of whom report being treated no differently from the many men. He made the same intellectual demands, invested the same amount of time and 
energy, and had the same expectations for success, regardless of gender, ancestry, or nationality. These women, along with his male trainees, subsequently made their own critical contributions.

"Being mentored by Arno was both humbling and enriching. He never pulled punches. He respected his trainees enough to disagree with them, sometimes vehemently. But he had no interest in knocking people down. Rather, he expected a trainee to defend his or her position, or accept the flaws in the argument and work with him to get to a better understanding of the problem. And unlike most mentors of his generation, it made no difference if the trainee was "him" or "her"," offered Wylie Burke, MD, retired University of Washington Chair of Bioethics and Humanities, who trained with Arno from 1978-1982. These comments are consistent with those of others.

Debra Freedenberg, MD, PhD, now Medical Director of the Newborn Screening and Genetics Unit for the Texas Department of State Health Services, who trained in 19851989, observed that "Having started genetics fellowship at a time when women in medicine were relatively rare, Arno was truly gender blind, wanting only the best training for those he mentored."

In spite of failing health, his intellectual contributions remained vibrant. As his health deteriorated, we saw him less in 2016, but he insisted on coming in for a seminar given by former University of Washington trainee and Genetics in Medicine editor James Evans. This turned out to be his last day at the University. True to form, he asked a perceptive question. He is greatly missed.

\section{REFERENCES}

1. Motulsky AG \& King MC The great adventure of an American human geneticist. Annu Rev Genomics Hum Genet 2016;17:1-15

2. Motulsky AG, Paul MH \& Durrum EL Paper electrophoresis of abnormal hemoglobins and its clinical applications; a simple semiquantitative method for the study of the hereditary hemoglobinopathies. Blood 1954;9:897-910

3. Epstein CJ, Graham CB, Hodgkin WE, Hecht F \& Motulsky AG Hereditary dysplasia of bone with kyphoscoliosis, contractures, and abnormally shaped ears. J Pediatr 1968;73:379-386

4. Omenn GS \& Motulsky AG Brain, genetics, and behavior. Science 1971;173:1255-1256

5. Goldstein JL, Hazzard WR, Schrott HG, Bierman EL \& Motulsky AG Genetics of hyperlipidemia in coronary heart disease. Trans Assoc Am Physicians 1972;85:120-138

6. Schrott HG, Goldstein JL, Hazzard WR, McGoodwin MM \& Motulsky AG Familial hypercholesterolemia in a large indred. Evidence for a monogenic mechanism. Ann Intern Med 1972;76:711-720

7. Motulsky AG The 1985 Nobel Prize in physiology or medicine. Science 1986;231:126-129

8. Nakamura J, Shernoff DJ, Hooker CH \& Csikszentmihalyi M Good Mentoring: Fostering Excellent Practice in Higher Education. Wiley: San Francisco, 2009 